\title{
Natural resources for the nature-based tourism development of the Vojvodina Province
}

\author{
Igor Trišić ${ }^{*}$ \\ ${ }^{1}$ University of Kragujevac, Faculty of Hotel Management and Tourism in Vrnjačka Banja, \\ Serbia
}

\begin{abstract}
The area of the Autonomous Province of Vojvodina has significant natural potentials for the development of nature-based tourism. The paper analyzes the data found in various articles as well as data obtained hands-on. Selected factors such as location, relief, climate, hydrography, flora and fauna and protected areas of Vojvodina were analyzed. The degree of presence of the mentioned factors for the development of nature-based tourism was determined with selected indicators. The medium and high level of the presence of factors indicates the possibility of developing ecotourism, scientific tourism, hunting, fishing, sports and recreation, bird watching, nautical, trips and other forms of tourism based on natural resources. Quantitative, comparative and data presentation methods were used in the research. The results of research can aid further research of nature-based tourism.
\end{abstract}

Keywords: nature-based tourism, AP Vojvodina, ecotourism, natural resources JEL classification: Z32, Q56, Q57

\section{Prirodni resursi za razvoj turizma baziranog na prirodi Vojvodine}

Sažetak: Prostor Autonomne pokrajine Vojvodine poseduje značajne prirodne potencijale za razvoj turizma baziranog na prirodi. U radu su analizirani podaci različitih pisanih dokumenata, kao i podaci dobijeni na terenu. Ispitivani su odabrani faktori kao što su: položaj, reljef, klima, hidrografija, biljni i životinjski svet i zaštićena područja Vojvodine. Stepen prisutnosti navedenih faktora za razvoj turizma utemeljenog na prirodi, utvrđen je uz pomoć odabranih indikatora. Srednji i visok nivo prisutnosti faktora ukazuje na mogućnost razvoja ekoturizma, naučno-istraživačkog, lovnog, ribolovnog, sportsko-rekreativnog, turizma posmatranja ptica, nautičkog, izletničkog i drugih formi turizma utemeljenih na prirodnim resursima. To je ujedno cilj ovog rada. U istraživanju su korišćene kvantitativna, komparativna i metoda prikaza podataka. Rezultati istraživanja mogu pomoći daljem istraživanju turizma utemeljenog na prirodi.

Ključne reči: turizam prirodnih resursa, AP Vojvodina, ekoturizam, prirodni resursi JEL klasifikacija: Z32, Q56, Q57 


\section{Introduction}

The paper focuses on the protected areas of Vojvodina and natural resources that are important for the development of nature-based tourism. The area of the Autonomous Province of Vojvodina is characterized by diverse natural resources for the development of various forms of tourism. The tourism form that protects and promotes natural values is nature-based tourism (Kostić et al., 2019). Nature-based tourism often refers to protected natural areas. The territory of Vojvodina covers 135 natural sites, the total area of which is 141,044.65 ha (Delić et al., 2017). This makes 6.56\% of the total area of Vojvodina. The relatively small amount of protected areas can be a starting point for the development of nature-based tourism. Nature-based tourism development would also condition the growth of protected areas (Job et al., 2017).

The Autonomous Province of Vojvodina has significant potentials for all forms of naturebased tourism development. Diverse relief features, favorable climate, many hydrographic, diverse and rare flora and fauna, and protected natural areas are all different significant natural potentials for the tourism development (Maksin et al., 2018). Natural-geographical features mostly form the complete life of a certain area. These conditions decide the role of each species in the systemic symbiosis where the human role is important. All human activities are closely related to the basic characteristics of the area in which the movement of tourists is realized. Changing certain elements of the environment directly affects the behavior and characteristics of species and the complete nature (Batman \& Demirel, 2016). Therefore, the geographical place of a certain area, relief and soil composition, climate, hydrography and biogeography, are the basic preconditions for the formation of the main features of Vojvodina, and can have a positive impact on the nature-based tourism development.

The area of Vojvodina has different ecosystems inhabited by many species. The protection of areas from external impact and user pressures can be realized through nature-based tourism. The development of tourism must take into account all the natural and geographical characteristics of the area in which it develops.

The goal of this paper is to research and analyze the natural resource base of protected areas of Vojvodina. That includes data found in various articles as well as data obtained hands-on such as location, relief, climate, hydrography, flora and fauna. The presence of certain natural factors will determine the selected indicators (Maksin et al., 2011).

The contribution to scientific research is reflected in the use of the results obtained in this research in the development of a strategy for nature-based tourism in Vojvodina. The paper centers on the natural factors of AP Vojvodina, which can have high importance for the development of nature-based tourism and sustainable tourism development.

The method of this paper includes the quantitative research method. The paper research method analyzes various written data about selected indicators of sustainability in protected natural areas of Vojvodina. After the analysis, with the comparative method, the most important factors that positively impact the development of tourism can be singled out.

\section{Background}

A feature of 21st-century tourism is the protection and improvement of nature (Bello et al., 2016). Tourists are increasingly choosing sustainable tourist destinations (Wardle et al., 2018). The reason is the wish of tourists for natural values to remain in the future. Naturebased tourism is a form of tourism that uses natural values (Eagles, 2014). Those are 
ecotourism, scientific-tourism, bird and animal watching, adventure tourism, sports tourism, trips, etc. (Štetić \& Trišić, 2018).

Vojvodina completely belongs to the Pannonian biogeographical region and represents a secondary forest-steppe area. Forests and wooded areas cover $6.8 \%$ of the territory. Natural specifics such as favorable climate, relief, flora and fauna, the richness of water resources, and protected areas, place this region in the highly promising areas for the development of nature-based tourism (Trišić et al., 2020; Torres-Delgado \& Saarinen, 2014; Valdivieso et al., 2015).

There are preserved natural and landscape areas, unique to this part of Europe, such as Deliblato Sands, Fruška Gora, and Vršac Mountains. The floodplains of the Danube, Sava, Tisa, Begej, Tamiš, Karaš, Nera, and Bosut River have been preserved on the lowest terrains, which represent a kind of oasis of flora and fauna, and most of them are in protection regimes precisely because of biological diversity (Noakes \& Bouvier, 2013). There are also large steppe areas in central and northern Banat, as well as loess-soil complexes along the Tisa and Danube River. Special mention should be made of the preserved salt marshes of Banat and the unique and specific habitats of salt lakes, which have priority in protection at the international and national levels. In AP Vojvodina, there is a significant network of protected areas, i.e. important centers of autochthonous biological diversity.

Due to this richness of different habitat types, the area of Vojvodina is characterized by a rich and specific species and ecosystem diversity. The characteristic of flora and fauna are the existence of endemic and endangered species. This is a basic condition for the development of nature-based tourism. This form of tourism aims to improve the value of the area (Buclet \& Lazarević, 2015).

The Autonomous Province of Vojvodina is situated in a very favorable geographical and tourism setting, which is reflected in the vicinity of neighboring countries and cities, a favorable hydrographic connection with many countries via the Danube, Sava, and Tisa as the most important rivers in Vojvodina (Lazić et al., 2008). This is another important condition for the development of nature-based tourism (Torres-Delgado \& Saarinen, 2014).

The development of nature-based tourism in AP Vojvodina can provide great economic benefits, both for the tourism destination and for the economy of AP Vojvodina. Economic revenues have a significant impact on the country's financial system (Leković, 2019).

\section{Materials and methods}

\subsection{Study area}

The Autonomous Province of Vojvodina is situated in the southern part of the Pannonian Plain, in Northern Serbia. It covers an area of $21,506 \mathrm{~km}^{2}$, it is $24.3 \%$ of the total territory of the Republic of Serbia (including Kosovo). The area of the Province is located between $44^{\circ} 38^{\prime}$ and $46^{\circ} 10^{\prime} \mathrm{N}$, and from $18^{\circ} 10^{\prime}$ to $21^{\circ} 15^{\prime} \mathrm{E}$ (Lazić et al., 2008).

Srem, Banat and Bačka are three geographical units of Vojvodina. The area of AP Vojvodina is a territorial and geographical unit that borders the Republic of Hungary to the north, Romania to the east, the Republic of Croatia to the west, the Republic of Bosnia and Herzegovina to the southwest (Figure 1). The southern border of Vojvodina is the administrative border with Central Serbia withal. The natural border of AP Vojvodina consists of the international navigable rivers the Danube towards the Republic of Croatia and central Serbia, and the Sava towards Bosnia and Herzegovina and central Serbia. 
Vojvodina has a favorable geographical and traffic location. The proximity of Belgrade and other European cities from the region is an important feature of the tourism development of Vojvodina.

Figure 1: Map of Vojvodina

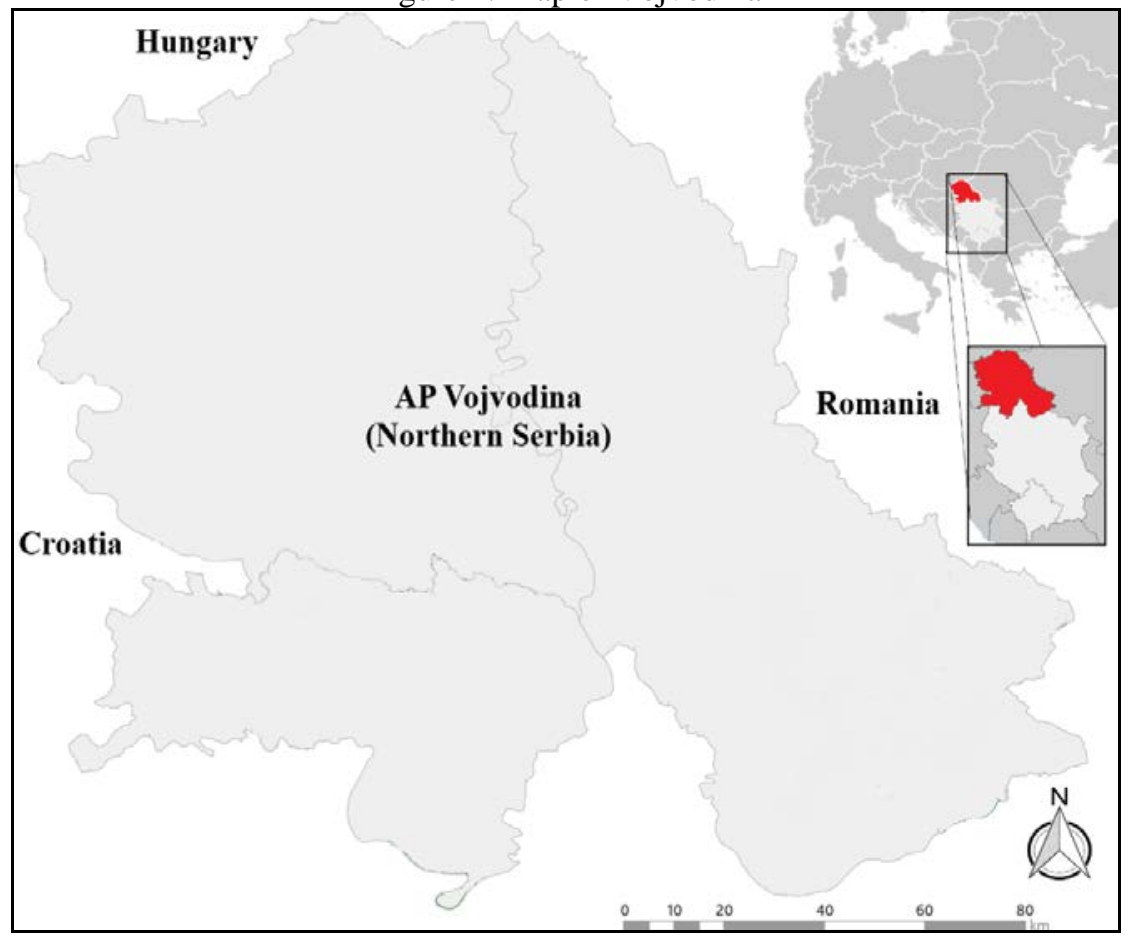

Source: Author digitalized

\subsection{Natural resources data}

The following main morphological units can be singled out in the relief of Vojvodina: mountains, sands, and alluvial plains. Mountain areas are Fruška Gora (539 m) and Vršac Mountain (641 m). Fruška Gora covers the southern and southwestern parts of Vojvodina, in the northern part of Srem, while the Vršac Mountains are located in the southeast of Vojvodina and Banat (Lazić et al., 2008). The area of the province consists of very rare biogeographical units, important for the formation of a unique ecosystem. Certain environmental conditions and natural processes have formed very specific terrains, many of which date from the early periods of soil formation. Most of them have special features, characteristic only for this area. Therefore, it should be considered important in the formation of this unique ecosystem. The rivers Danube, Tisa, Sava, Tamiš, Zlatica, and Begej have the largest alluvial plains in Vojvodina (Tomić et al., 2004).

The climate of Vojvodina is moderately continental with certain specifics. The average annual temperature is about $11^{\circ} \mathrm{C}$. Summer temperatures are between $21^{\circ} \mathrm{C}$ and $23^{\circ} \mathrm{C}$ and winter around $-2^{\circ} \mathrm{C}$. However, temperatures can be extreme to the extent that that the difference between the highest and lowest temperatures amounts to over $70^{\circ} \mathrm{C}$. The average annual amount of precipitation in Vojvodina ranges from 550 to $600 \mathrm{~mm} / \mathrm{m}^{2}$, where extremely rainy periods at the beginning of summer (June) and periods without or with a small amount of precipitation (October and March) can be distinguished (MalinovićMilićević et al., 2018). 
The river networks of AP Vojvodina consist of three large rivers: the Danube, Sava, and Tisa, with all their tributaries and canals. The Danube, which flows through Serbia with a length of 588 kilometers and through Vojvodina with a length of $358 \mathrm{~km}$, is navigable along the whole length (Štetić et al., 2014). Also, important are the Danube tributaries the Tisa $(168 \mathrm{~km})$, the Sava $(206 \mathrm{~km})$ and the Begej $(75 \mathrm{~km})$, between which a branched network of irrigation, drainage and transport canals were dug, with a total length of $939 \mathrm{~km}$, of which $673 \mathrm{~km}$ are navigable. All rivers are characterized by a small fall, slow and winding course, high accumulative power and a tendency to create marshes and meanders, which gives great convenience for the formation of wetlands important for the flora and fauna (Tomić et al., 2004). The hydrographic network also includes lakes, the most important of which are Palić Lake near Subotica $\left(5,8 \mathrm{~km}^{2}\right)$, Ludaš Lake, and other lakes in Fruška Gora and Bačka. Wetlands are protected by special protection regimes, to preserve the unique habitats (Mitsch et al., 2015). Wetlands are highly productive ecosystems that produce wilder species and primary plants, both in number and diversity, more than any other habitat on Earth (Holden, 2016).

Flora and fauna represent a significant natural potential for the development of nature tourism. Species protection forms areas that are suitable for nature-based tourism development. There are over 2,000 species of plants and animals in the province (Stojnić et al., 2015). Biological diversity on the territory of AP Vojvodina and the number of individual species can be shown in Table 1.

Table 1: The overview of the diversity of selected species

\begin{tabular}{|c|c|c|}
\hline Total species & AP Vojvodina & Republic of Serbia \\
\hline Vascular plants & 2,000 & 3,562 \\
\hline Fishes & 75 & 100 \\
\hline Amphibians & 17 & 23 \\
\hline Reptiles & 14 & 24 \\
\hline Breeding birds & 193 & 237 \\
\hline Mammals & 75 & 98 \\
\hline
\end{tabular}

Source: Author, based on Stojnić et al., 2015

Many species have the endangered status. In the category of Critically Endangered (CR), 28 species and subspecies were recorded. To this group of taxa some extremely rare species should be added that have recently been recorded only in Vojvodina, such as Elatine hungarica, Cerastium subtetrandrum and Hierochloe repens. In the category of Endangered (EN), 50 species were recorded, and in the category of Vulnerable (VU), 40 species were recorded. Other species (82), due to the lack of data needed to assess the exact endangered category, fall into combined categories. In App. I, strictly protected plant species, 1992 and 1999 rev., Appendix 1/Annexe 1, 16 species with four subspecies are listed. On the CITES List - Convention on International Trade in Endangered Species of Wild Fauna and Flora, Appendix 2, 46 species and subspecies are listed (Report on the implementation of the program for the natural resources protection for 2017, 2018).

The area of AP Vojvodina is inhabited by 75 species of mammals, classified in six orders: Insectivora, Chiroptera, Rodentia, Lagomorpha, Carnivora and Artiodactyla are $76.5 \%$ of the total number of mammals (98) in the Republic of Serbia (Code on the declaration and protection of strictly protected and protected wild species of plants, animals and fungi (Offical Gazette of RS, no. 5/2010, 47/2011, 32/2016 and 98/2016). It should be noted that the Wild Cat (Felis silvestris) is a strictly protected species only in the territory of Vojvodina, while the Wolf (Canis lupus) has the status of a strictly protected species in this territory, except in the hunting grounds of Deliblato Sands and Vršac Mountains, where it is 
protected as a protected wild species. Important representatives of endangered fauna are Eurasian Otter (Lutra lutra), Eurasian Beaver (Castor fiber) and Wild Cat (Felis silvestris). There are three allochthonous species: Fallow Deer (Dama dama), White-tailed Deer (Odocoileus virginianus) and Mouflon (Ovis orientalis), which were introduced in the middle of the last century in some fenced hunting grounds (Karađorđevo and Subotica woods) to increase game (Delić et al., 2017).

Out of the total of 307 strictly protected bird species in Serbia, 283 species have been registered in Vojvodina. Among the most endangered, globally and regionally breeding birds of Vojvodina are Great Bustard (Otis tarda) (BirdLife International, 2017a; Martin et al., 2000), White-tailed Eagle (Haliaeetus albicilla) (Korsman et al., 2012), Imperial Eagle (Aquila heliaca) (BirdLife International, 2017b), and Saker Falcon (Falco cherrug).

Out of 24 species of reptiles that live on the territory of Serbia, the area of Vojvodina is inhabited by 16 species. Of that number, 10 species are strictly protected, while two are protected (Stojnić et al., 2015).

With 21 registered amphibian species, Serbia ranks second among the Balkan countries in terms of batrachofauna, just behind Greece, which has 22 registered species. In Serbia, there are $25 \%$ of the species of the known 85 species, which inhabit the whole of Europe. Of that number, the area of Vojvodina is inhabited by 16 species, of which 13 are strictly protected, and three species have the status of protected.

About 75 species of freshwater fish from 17 families were recorded in watercourses and stagnant waters on the territory of AP Vojvodina. Out of 30 strictly protected fish species and 34 protected fish species in Serbia, 17 strictly protected and 28 protected fish species were recorded in the area of Vojvodina (Stojnić et al., 2015). European Mudminnow (Umbra krameri), is the most important protected fish, and the only representative specie of the Umridae family in Europe, and endemic to the Danube Basin (Freyhof, 2013). According to the IUCN Red List of Threatened Species, European Mudminnow has the status of a vulnerable species - Vulnerable A2c. At the national level, it has the status of a critically endangered species (CR) and is in imminent danger of extinction. There are other strictly protected species of fish: Sunbleak (Leucaspius delineatus), Tench (Tinca tinca), Amur Bitterling (Rhodeus sericeus), and Balkan Loach (Cobitis elongata). Protected species are also present in the inland waters of Vojvodina: Common Bream (Abramis brama), Blue Bream (Ballerus ballerus), Asp (Leuciscus aspius), Common Barbel (Barbus barbus), Carp (Cyprinus carpio), Ide (Leuciscus idus), Burbot (Lota lota), Pike (Esox lucius), Zander (Sander lucioperca), and European Perch (Perca fluviatilis) (Stojnić et al., 2015).

\subsection{Methods}

The quantitative research method included an analysis of natural resources that are important for the development of nature-based tourism. A total of 34 indicators representing natural factors important for the development of nature-based tourism were examined (EU, 2013; Konu \& Kajala, 2012; Maksin et al., 2011; WTO, 2004). The indicators were confirmed by inspecting various written documents and partially confirmed in the field. The scores of the examined indicators are Low (L), Medium (M) and High $(\mathrm{H})$. The obtained results can represent a significant basis for determining the possibility of developing nature-based tourism (Maksin et al., 2011; Puzović et al., 2015). After the presentation of the selected natural base, unified comparative analysis of these selected indicators will be performed. The comparative analysis will provide significant answers to the extent to which the natural base is important for the development of nature-based tourism (Torres-Delgado \& Saarinen, 2014). 


\section{Results and discussion}

Table 2 presents selected indicators that represent the existence of certain factors relevant to nature-based tourism forms (Maksin et al., 2011).

Table 2: Analysis of selected indicators for the development of nature-based tourism

\begin{tabular}{|c|c|c|}
\hline \multicolumn{2}{|r|}{ Indicators } & Results \\
\hline 1. & The favorable location of AP Vojvodina & $\mathrm{H}$ \\
\hline 2. & Favorable relief & $\mathrm{H}$ \\
\hline 3. & Favorable climate & $\mathrm{H}$ \\
\hline 4. & Hydrographic objects and wetlands & $\mathrm{H}$ \\
\hline 5. & Different species of plants and animals & $\mathrm{H}$ \\
\hline 6. & Endemic species & $\mathrm{M}$ \\
\hline 7. & Endangered species according to IUCN & $\mathrm{L}$ \\
\hline 8. & Species reintroduction & $\mathrm{L}$ \\
\hline 9. & Protected areas & $\mathrm{M}$ \\
\hline 10. & National area protection status & $\mathrm{M}$ \\
\hline 11. & International area protection status & $\mathrm{L}$ \\
\hline 12. & Sufficient number of supporting tourism facilities & $\mathrm{M}$ \\
\hline 13. & Accommodation service & $\mathrm{L}$ \\
\hline 14. & Available visitor center & $\mathrm{M}$ \\
\hline 15. & Marked walking and educational trails & $\mathrm{M}$ \\
\hline 16. & Developed ecotourism & $\mathrm{L}$ \\
\hline 17. & Developed scientific tourism & $\mathrm{M}$ \\
\hline 18. & Developed photographing birds and animals & M \\
\hline 19. & Developed bird and animal watching & $\mathrm{M}$ \\
\hline 20. & Hunting tourism & M \\
\hline 21. & Sports tourism & M \\
\hline 22. & The availability of mountain tourism & $\mathrm{H}$ \\
\hline 23. & Fishing & $\mathrm{H}$ \\
\hline 24. & The availability of trips & $\mathrm{L}$ \\
\hline 25. & Promotion of nature-based tourism & $\mathrm{L}$ \\
\hline 26. & The role of the local community in management protection & $\mathrm{L}$ \\
\hline 27. & The availability of ethno-villages or settlements & M \\
\hline 28. & Unplanned construction & $\mathrm{H}$ \\
\hline 29. & The proximity to potential environmental pollutants & M \\
\hline 30. & The use of natural resources & $\mathrm{H}$ \\
\hline 31. & The presence of domestic animals & $\mathrm{H}$ \\
\hline 32. & The proximity to agricultural land & $\mathrm{H}$ \\
\hline 33. & Eliminated the problem of wastewater from the settlements & M \\
\hline 34. & Tourism development planning & $\mathrm{M}$ \\
\hline
\end{tabular}

Source: Author, based on Maksin et al., 2011 and Puzović et al., 2015

The analysis of the assessed indicators concludes that the Autonomous Province of Vojvodina has a relief that is characteristic of lowland areas, which has a favorable impact on the climate and the formation of ecosystems in this area. Also, it is concluded that the relief greatly impacts the adoption of protection measures for various spatial units, and therefore the constitution of protected natural areas and sites of Vojvodina, important for the conservation of these valuable biogeographical units. This relief has a positive effect on the development of nature-based tourism (Lazić et al., 2008). 
The climate of a certain area, together with its morphology, defines the type of vegetation that can be characteristic and endemic to a place, although people often change it over time. Proper analysis of biogeography is essential for the management of most tourism destinations, which are important for all outdoor activities, including nature-based tourism. Climate has a direct impact on the biogeographical distribution of natural vegetation in the region. The favorable climate of Vojvodina has had a significant impact on the characteristic flora and fauna in this area, in terms of the diversity of organisms, some of which are endemic. The same favorable impact was reflected in the formation of characteristic habitats such as the eolian and wetland, which again represent rare forms of geodiversity, characteristic of the province. This represents a significant basis for the development of nature-based tourism. This form of tourism in Vojvodina can be developed throughout the year.

Many protected natural areas on the territory of the Autonomous Province of Vojvodina are precisely wetlands with rare plant and animal species, which mutually form a single biogeographical diversity (Stojanović et al., 2018). There are also numerous lakes and ponds of fluvial, eolian and artificial origin. The Vojvodina marshes are a subject of interest in the UNESCO because they form a kind of oasis of the natural world. Wetlands represent significant potential for the development of science tourism, ecotourism, fishing, sports tourism, bird watching, and other forms of nature-based tourism.

In addition to the above, the scientific-educational and recreational significance of the natural base should be emphasized, because these areas are also terrains with attractive motives for tourism (Vujović et al., 2018). All this confirms the interest of various economic and social structures in the use of the space of Vojvodina. Therefore, it is necessary to harmonize all these needs and put them in correlation with the function of nature protection and the development of nature-based tourism.

The flora and fauna represent a significant resource of this area. Protection systems are established with the aim of conserving these values because these areas very often suffer different and high levels of impact from users, due to their attractive attributes. Visits to certain areas are accompanied by intensive construction and the presence of other entities that draw on the resources of the environment. Prohibited hunting and the impact of prohibited agricultural chemicals on the flora and fauna are no less present. Each of these changes in the elements of the environment affects the reduction or destruction of species and thus biodiversity. The protection of flora and fauna is the basis for the development of nature-based tourism. By spending money in these tourist destinations, one directly invests in protection. The economic factor is a factor in all activities and tourism as well (Leković, 2020).

\section{Conclusion}

The Autonomous Province of Vojvodina has a variety of natural resources for the development of nature-based tourism. There are various reliefs, climate, hydrography, flora and fauna and protected natural areas. Tourism of the 21st century is characterized by tourists who are increasingly enjoying nature. Tourism uses natural resources. By examining selected indicators of the development of nature-based tourism, the connection between nature and tourism can be established. Research results of this article indicate that certain natural resources are important for nature-based tourism development (Delić et al., 2017). The high significance " $\mathrm{H}$ " has indicators as location, relief, climate, hydrographic objects including wetlands, different species of plants and animals and availability of mountain tourism, fishing. Indicators with a medium "M" result are endemic species, natural area protection status, the sufficient number of supporting tourism facilities, available visitor 
center, marked walking and educational trails, developed scientific tourism, sports tourism, bird and animal watching, natural photographing and hunting tourism. These research results will be used for the nature-based tourism strategies of protected natural areas of Vojvodina (Lazić et al., 2008). These natural factors are important for tourism development. The factors that are marked as low ("L") are: endangered species according to IUCN, species reintroduction, international area protection status, accommodation service, developed ecotourism, the availability of trips, promotion of nature-based tourism and the role of the local community in management protection (Krstić et al., 2020). These natural factors need to be improved with various strategies of development (Buclet \& Lazarević, 2015; Cvijanović et al., 2020).

The relief of Vojvodina enables the development of mountains, trips and sports tourism. The mountains Fruška Gora and Vršac Mountains are important for that. The climate allows the development of nature-based tourism throughout the year. Moderate temperature and precipitation do not have an impact on tourist activities. Flora and fauna represent significant tourist potential. The forms of tourism in which the main motive for travel is flora and fauna are ecotourism, adventure tourism, bird and animal watching, sports tourism, trips and other forms of nature-based tourism. The endangerment of flora and fauna affect the formation of protected natural areas. This impacts the development of scientific tourism. The analysis of the research results leads to the conclusion that the natural resources of protected areas in Vojvodina have an impact on nature-based tourism. Due to the distinct natural potentials, nature-based tourism should be developed. The realization of nature-based tourism can generate significant income. A large part of the income can be invested in the protection of areas, development of tourism infrastructure and all forms of tourism. This is the result of the research in this paper. The limitation of the research is that there are numerous settlements in the area of protected areas. The majority of the population of these settlements use resources of protected natural areas for their own needs and daily activities and it was difficult to separate them from the tourist use.

The research results will be used for future research of sustainable tourism development which is based on natural resources and the improvement of natural values.

\section{References}

1. Batman, Z. P., \& Demirel, O. (2016). Importance of ecology-based tourism and tourism planning approach in Meryemana Creek (Macka-Trabzon) Route. Journal of Environmental Protection and Ecology, 17(3), 1084-1094.

2. Bello, F. G., Carr, N., \& Lovelock, B. (2016). Community participation framework for protected area-based tourism planning. Tourism Planning \& Development, 13(4), 469485. https://doi.org/10.1080/21568316.2015.1136838

3. BirdLife International. (2017a). Otis tarda. The IUCN Red List of Threatened Species 2017: e.T22691900A119044104. https://doi.org/10.2305/IUCN.UK.20173.RLTS.T22691900A119044104.en

4. BirdLife International. (2017b). Aquila heliaca. The IUCN Red List of threatened species 2017: e.T22696048A117070289. https://doi.org/10.2305/IUCN.UK.20173.RLTS.T22696048A117070289.en

5. Buclet, N., \& Lazarević, D. (2015). Principles for sustainability: The need to shift to a sustainable conventional regime. Environment, Development and Sustainability, 17(1), 83-100. https://doi.org/10.1007/s10668-014-9539-4

6. Cvijanović, D., Stanišić, T., Leković, M., \& Kostić, M. (2020). Indicators of agricultural and rural development in the East Central and South-East European 
Trišić, I. - Natural resources for the nature-based tourism development of the Vojvodina ProvinceHotel and Tourism Management, 2020, Vol. 8, No. 2: 101-112.
countries.
Agriculture
\& Forestry,
$66(2)$
$19-32$.

https://doi.org/10.17707/AgricultForest.66.2.02

7. Delić, D., Cvijanović, D., \& Prentović, R. (2017). Uticaj lovnog turizma na zaštićena područja [The impact of hunting tourism on the protected areas]. Vrnjačka Banja: Univerzitet u Kragujevcu, Fakultet za hotelijerstvo i turizam u Vrnjačkoj Banji.

8. Eagles, P. F. J. (2014). Research priorities in park tourism. Journal of Sustainable Tourism, 22(4), 528-549. https://doi.org/10.1080/09669582.2013.785554

9. European Union (EU). (2013). European tourism indicator system toolkit for sustainable destinations. Brussels: European Commission EU.

10. Freyhof, J. (2013). Umbra krameri. The IUCN Red List of Threatened Species 2013: e.T22730A9380477. https://doi.org/10.2305/IUCN.UK.2008.RLTS.T22730A9380477.en

11. Holden, A. (2016). Environment and tourism. London: Routledge, Taylor Francis Group.

12. Izveštaj o sprovođenju programa zaštite prirodnih dobara za 2017. godinu [Report on the implementation of the program for the natural resources protection for 2017]. (2018). Novi Sad: Republika Srbija, Autonomna pokrajina Vojvodina, Pokrajinski zavod za zaštitu prirode.

13. Job, H., Becken, S., \& Lane, B. (2017). Protected areas in a neoliberal world and the role of tourism in supporting conservation and sustainable development: An assessment of strategic planning, zoning, impact monitoring, and tourism management at natural World Heritage Sites. Journal of Sustainable Tourism, 25(12), 1697-1718. https://doi.org/10.1080/09669582.2017.1377432

14. Konu, H., \& Kajala, L. (2012). Segmenting protected area visitors based on their motivations. Vantaa: Metsähallitus.

15. Korsman, J. C., Schipper, A. M., Lenders, H. J. R., Foppen, R. P. B., \& Hendriks, A. J. (2012). Modelling the impact of toxic and disturbance stress on white-tailed eagle (Haliaeetus albicilla) populations. Ecotoxicology, 21, 27-36. https://doi.org/10.1007/s10646-011-0760-8

16. Kostić, M., Ratković, M., \& Forlani, F. (2019). Eco-hotels as an example of environmental responsibility and innovation in savings in the hotel industry. Menadžment u hotelijerstvu i turizmu - Hotel and Tourism Management, 7(2), 47-56. https://doi.org/10.5937/menhottur1902047K

17. Krstić, V., Đurađević, M., \& Trišić, I. (2020). The impact of complementary medicine on sustainable tourism development through event and nature-based tourism. Economics of Agriculture, 67(2), 377-390. https://doi.org/10.5937/ekoPolj2002377K

18. Lazić, L., Pavić, D., Stojanović, V., Tomić, P., Romelić, J., Pivac, T., ... Kicošev, S. (2008). Zaštićena prirodna dobra i ekoturizam Vojvodine [Protected natural resources and ecotourism in Vojvodina]. Novi Sad: Univerzitet u Novom Sadu, Prirodnomatematički fakultet, Departman za geografiju, turizam i hotelijerstvo.

19. Leković, M. (2019). Behavioral portfolio theory and behavioral asset pricing model as an alternative to standard finance concepts. Economic Horizons, 21(3), 255-271. https://doi.org/10.5937/ekonhor1903263L

20. Leković, M. (2020). Cognitive biases as an integral part of behavioral finance. Economic Themes, 58(1), 75-96. https://doi.org/10.2478/ethemes-2020-0005

21. Maksin, M., Pucar, M., Milijić, S., \& Korać, M. (2011). Održivi razvoj turizma u Evropskoj uniji i Srbiji [Sustainable development of tourism in the EU and Serbia]. Beograd: Institut za arhitekturu i urbanizam Srbije.

22. Maksin, M., Ristić, V., Nenković-Riznić, M., \& Mićić, S. (2018). The role of zoning in the strategic planning of protected areas: Lessons learnt from EU countries and Serbia. $\begin{array}{llll}\text { European } & \text { Planning } & \text { Studies, } & \text { 26(4), }\end{array}$ https://doi.org/10.1080/09654313.2018.1426736 
23. Malinović-Milićević, S., Mihailović, D., Radovanović, M., \& Drešković, N. (2018). Extreme precipitation indices in Vojvodina region (Serbia). Journal of the Geographical Institute "Jovan Cvijic”, SASA, 68(1), 1-15. https://doi.org/10.2298/IJGI1801001M

24. Martin, C. A., Alonso, J. C., Alonso, J. A., Morales, M. B., \& Pitra, C. (2000). An approach to sexing young Great Bustards Otis tarda using discriminant analysis and molecular techniques. Bird Study, 47, 147-153. https://doi.org/10.1080/00063650009461170

25. Mitsch, W. J., Bernal, B., \& Hernandez, M. E. (2015). Ecosystem services of wetlands. International Journal of Biodiversity Science, Ecosystem Services \& Management, 11(1), 1-4. https://doi.org/10.1080/21513732.2015.1006250

26. Noakes, D. L. G., \& Bouvier, L. D. (2013). Threatened fishes of the world: the end of a series. Environmental Biology of Fishes, 96, 1135-1149. https://doi.org/10.1007/s10641-013-0174-y

27. Pravilnik o proglašenju $i$ zaštiti strogo zaštićenih $i$ zaštićenih divljih vrsta biljaka, životinja i gljiva (,Službeni glasnik RS”, broj 5/2010, 47/2011, 32/2016 i 98/2016) [Code on the declaration and protection of strictly protected and protected wild species of plants, animals and fungi (“Offical Gazette of RS”, no. 5/2010, 47/2011, 32/2016 and 98/2016)].

28. Puzović, S., Panjković, B., Tucakov, M., Stojnić, N., Sabadoš, K., Stojanović, T., ... Stanišić, J. (2015). Upravljanje prirodnom baštinom u Vojvodini [Natural heritage management in Vojvodina]. Novi Sad: Republika Srbija, Autonomna Pokrajina Vojvodina, Pokrajinski sekretarijat za urbanizam, graditeljstvo i zaštitu životne sredine, Pokrajinski zavod za zaštitu prirode.

29. Stojanović, V., Lazić, L., \& Đunić, J. (2018). Nature protection and sustainable tourism interaction in selected Ramsar sites in Vojvodina (Northern Serbia). Geographica Pannonica, 22(3), 201-207. https://doi.org/10.5937/gp22-16637

30. Stojnić, N., Panjković, B., Sabadoš, K., Kicošev, V., Timotić, D., Kiš, A., ... Pivaš, B. (2015). Izveštaj o stanju prirode u Autonomnoj pokrajini Vojvodini za period 20102014 [Report on nature condition in Autonomous Province of Vojvodina for period 2010-2014]. Novi Sad: Republika Srbija, Autonomna Pokrajina Vojvodine, Pokrajinski zavod za zaštitu prirode.

31. Štetić, S., \& Trišić, I. (2018). The role and importance of ecosystems in creating tourism activities. Menadžment u hotelijerstvu i turizmu - Hotel and Tourism Management, 6(2), 35-46. https://doi.org/10.5937/menhottur1802043S

32. Štetić, S., Cvijanović, D., \& Šimičević, D. (2014). Posebni oblici turizma Dunavskog regiona Srbije [Specific forms of tourism in the Danube Region of Serbia]. Beograd: Institut za ekonomiku poljoprivrede.

33. Tomić, P., Romelić, J., Kicošev, S., \& Lazić, L. (2004). Vojvodina, naučno popularna monografija [Vojvodina, scientifically-popular monograph]. Novi Sad: Društvo geografa Vojvodine.

34. Torres-Delgado, A., \& Saarinen, J. (2014). Using indicators to assess sustainable tourism development: a review. Tourism Geographies: An International Journal of Tourism Space, Place and Environment, 16(1), 31-47. https://doi.org/10.1080/14616688.2013.867530

35. Trišić, I., Štetić, S., Privitera, D., \& Nedelcu, A. (2020). Wine routes in Vojvodina Province, Northern Serbia - a tool for sustainable tourism development. Sustainability, 12(1), 82. https://doi.org/10.3390/su12010082

36. Valdivieso, J. C., Eagles, P. F. J., \& Gil, J. C. (2015). Efficient management capacity evaluation of tourism in protected areas. Journal of Environmental Planning \& Management, 58(9), 1544-1561. https://doi.org/10.1080/09640568.2014.937479 
Trišić, I. - Natural resources for the nature-based tourism development of the Vojvodina ProvinceHotel and Tourism Management, 2020, Vol. 8, No. 2: 101-112.

37. Vujović, S., Premović, J., \& Spajić, J. (2018). Aspekti održivosti menadžment procesa stvaranja materijalne osnove turizma [Sustainability aspects of managerial process of creating material basis for tourism]. Zbornik radova Filozofskog fakulteta u Prištini, 48(4), 297-310. https://doi.org/10.5937/ZRFFP48-19302

38. Wardle, C., Buckley, R., Shakeela, A., \& Castley, J. G. (2018). Ecotourism's contributions to conservation: Analysing patterns in published studies. Journal of Ecotourism, 1-31. https://doi.org/10.1080/14724049.2018.1424173

39. World Tourism Organization (WTO). (2004). Indicators of sustainable development for tourism destinations: A guidebook. Madrid: WTO.

Received: 12 May 2020; Sent for revision: 14 July 2020; Accepted: 31 July 2020 